\title{
Model Confirmation through Qualitative Research: Social Support System toward Entrepreneurial Desire
}

\author{
M. Amsal. Sahban ${ }^{1}$, Dileep Kumar M. ${ }^{1} \&$ Subramaniam Sri Ramalu ${ }^{1}$ \\ ${ }^{1}$ Othman Yeop Abdullah Graduate School of Business, Universiti Utara Malaysia, Malaysia \\ Correspondence: M. Amsal. Sahban, Othman Yeop Abdullah Graduate School of Business, Universiti Utara \\ Malaysia, Malaysia. E-mail: amsalsahban@yahoo.com
}

Received: June 9, 2014 Accepted: August 7, 2014 Online Published: October 30, 2014

doi:10.5539/ass.v10n22p17

URL: http://dx.doi.org/10.5539/ass.v10n22p17

\begin{abstract}
Entrepreneurial world is trying their best level to attract university graduates across the world. Indonesian culture is still very colonial view that the status of employment is more respectable than being an entrepreneur. In addition, people often perceive that a university degree is much better and more important than a person's ability or skill. In fact, the skill is very much needed to support a person's life economically, instead of looking for a university degree first then searching the skill or capability. This is one of the fact encountered that most of them who have a university degree but unemployed. In Indonesia, the number of scholars unemployed is getting higher statistically because most of them only rely on job vacancies, instead of becoming job creators. There is no motivation from various environments like family, friend, educational institution, etc. to build student's mentally strong with business awareness to deal with entrepreneurial issues. Yet, when someone interested in pioneering new business, they are desperately in need of an endorsement. Entrepreneurial support usually comes from a family, partner, peers and educational institutions where they can discuss the idea of becoming an entrepreneur and entrepreneurial issues further seeking best of suggestions. A study of qualitative was conducted among Indonesian universities and their social environment that identify the factors influencing social support among business graduate students to become an entrepreneur. The study follows focused group discussion, interviews, case analysis and Delphi technique to arrive at appropriate variables on social support factors among business graduates. The study observed 2 dimensions of social support that eventually suit the attitude of business graduates to become an entrepreneur. These elements were recognized by the group of professionals from various fields. This study provides an insight into the variables of social support among business graduates to become an entrepreneur in Indonesia. It is expected that the graduates later become the inspiration for others who are capable of creating jobs and giving a contribution to improve economic development in Indonesia. A business awareness and social supports are very much needed among university graduates by changing their mindset in dealing with entrepreneurship.
\end{abstract}

Keywords: social support, entrepreneurship, motivation, students

\section{Introduction}

Decades ago, Schumpeter (1934) once said that "essentially, the entrepreneurs will drive the economy." This statement is really tragic if it is linked to Indonesian economy with a high rate of unemployment and lack of job opportunities. A good entrepreneurial climate, in fact, will be able to overcome this severe problem. However, it is not that simple to start a new business. Many people who are engaged in small business like street ventures, small shoppers, etc. are perceived as almost equal to unemployed and are not considered as good ventures by the Indonesian community. While these small businesses are extending better turnover and good return on investment to the business starters. Here, the small ventures are associated with social stigma that these entrepreneurial Jobs are less prestigious as a government job. Whereas, it is obvious that when someone intends to pioneer new business, he desperately needs a support. Support for entrepreneurship usually comes from a family, partner and peers where they can discuss the idea and the problems encountered along with the ways to handle the problem (Mustikawati \& Bachtiar, 2008). Substantiating these issues, one study also revealed that the existence of a social risk associated with starting a business, therefore the fear of being demeaned and ridiculed when facing a failure in business and there is a negative perception toward the failure (Phikala \& Vesatlenein, 2009). Meanwhile, most the parents of university students perceive that the risk of being an entrepreneur is too 
high (Hartanto, 2011). Such negative assumption sometimes becomes a constraint and discourages someone to start with entrepreneurship.

In a study, Amalia (2012) further found that the students have less confidence to be entrepreneur. They do not have the support of parents to become an entrepreneur. Parents tend to expect their children to work in a company instead of being an entrepreneur. A lot of parents often unconsciously forcing the will of their children and the parents are unable to distinguish between their desire and the children's desire (Mustikawati \& Bachtiar, 2008).

\section{Literature Review}

It appears to be widely known in most studies that social support is a multifarious and multidimensional construct, there are lots of disagreements on exactly how it is best conceptualized, interpreted and/or measured (e.g., Barrera, 1986; Thompson, 1995; Lakey \& Cohen, 2000; Lopez \& Cooper, 2011).

Social support is a pleasant feeling, having attention, self-esteem or the aid received by people or group (Cobb, 1985). Further Cobb (1985) emphasizes social support on personal ownership toward the social communication networks and the need to cooperate with each other. Social support is generally defined as the presence of other people who can be trusted, people that make others loved for, pleasures that cannot be quantifiable. Sarason et al. (1987) explains social support as a regular interaction with other people and immediate family members or relating to the provision of duties and attachments. Social support is the social way of communicating with others to manifest love and care for others. This kind of support serves as building blocks of social, psychological and biological integrity. Both formal and informal support networks have been seen as a central element of an individual's social capital, a valuable resource that contributes to better health chances (Goodwin, Costa, \& Adonu, 2004).

Social support in reality can be understood as caring for one, providing for the needs of others, strengthening the social network of people globally. These resources that a given to others can be emotional, for example, in providing for the financial needs, providing adequate information for them and giving them a wonderful advice.

Social support comprises of the characteristics of a good social relationship among people, readiness to give them assistance. It happened through a close relationship to others, for their right to keep an obligation and to maintain good will with others. Social support can be explained in a different way, depending on one's understanding relating to it. It can be described as a resource giving to others, embracing care for others or giving out one's resources to others. Different type of social support have been identified like the instrumental support that can help to solve a problem on how people feel for others as well as reasonable support for like giving of goods and good advice but to mention a few (Schwarzer \& Rieckmann, 2000).

Social support refers to the potential entrepreneur's beliefs and expectations about the support he or she will receive from groups to which he/she belongs (parents, siblings, and spouse) and from other reference groups (friends, colleagues, and teachers) in the case of setting up a business or going self-employment (León, Descals, \& Domínguez, 2007).

Albrecht and Adelman interpreted social support as interaction between recipients and providers that diminish uncertainty about the situation, the relationship or others and functions to enhance the perception of personal control in one's life experience. Referring to this definition, according to Mattson's Health as Communication Nexus (2011) the basic features of social support includes:

- Communication

- Uncertainty reduction

- Enhanced control

Based on this definition, social support refers to an approach of having a good interaction to other people with the aim of addressing their needs and affecting them positively to be a better person and to be in charge of any giving circumstances they find themselves in (Mattson's Health as Communication Nexus, 2011).

Hupcey (1998) describes social support is a multi-faceted ideology that is very complicated to understand, to explain and to measure. Despite this idea has been widely looked into, there is few acceptance among researchers as to its theoretical and applying its definition. Therefore, the understanding remains unclear and everything that relates to social relationship could be regarded as social support. Researchers of social support have constantly neglected the difficulty of the concept and the measurements relating to the changes in its simplicity. He also suggested that social support with a good attitude to others helps to maintain a good relationship with others and gives a positive respond from the receiver (William, 2005). 
Social support relates to tangible outcomes such as the actual and potential resources individuals obtain from knowing others, being part of a social network with them or merely from being known to them and having a good reputation (Baron \& Markman, 2000; Mair \& Noboa, 2003). It was believed that the social support theory pays attention to three interrelated classes of variables like personal characteristics, interpersonal relationships and the factors that generate supportive efforts. These variables can be considered as context of social support since the influence of social support rely on the interaction of the above three dimensions (Sarason et al., 1992; Rasheed, Sawal, Taj, \& Najam, 2005).

Social support contains a multidimensional collection of material, emotional, or informational resources. These resources are provided through social connections with family, friends, groups, or professionals (Harris, 2006). Gottlieb (2000) cited in Mattson's Health as Communication Nexus (2011) defined social support more broadly as the process of interaction which can enhance coping, respect, belonging, and capability through actual or perceived exchanges of physical or psychosocial resources". Referring to this explanation the main components of social support are:

- Interaction

- Coping

- Esteem

- Belonging

- Competence

- Exchange

Sarafino (1994) cited in Mustikawati dan Bachtiar (2008) classified a social support in 5 dimensions as follows:

1) Emotional support

This support involves the expression of empathy and concern for individual, so the individual feel comfortable, feel loved and cared. Closed network of contacts around the entrepreneur, in which the contacts know each other, generate trust within the network. Trust between actors will escalate the likelihood that the entrepreneur may acquire sensitive information and emotional support (Klyver \& Schøtt, 2011).

\section{2) Esteem Support}

This refers to a positive assessment on the individual, encouragement and approved statement on individual opinion. This support will help the valuable feeling for those who consider themselves to have different abilities with others, so that it can improve self-confidence and self-esteem to the individuals.

3) Tangible or instrumental support

It refers to cash transfer such as money or other material.

4) Informational support

A support that includes the provision of advice, guidance, suggestions or feedback on how to solve the problem. Such support can help the individual to recognize and address a problem easily.

\section{5) Network support}

This support leads to a sense of belonging to the individual because the individual has become a member in a group. In this case, the individual can share interests and social activities, so that the individual feels himself to be accepted by the group.

Emotional support is the most important social support, including sympathy, concern, love and trust. Especially, it can be realized by an operational definition such as providing self-respect, friendship, trust, concern, and hearing (Wei \& Wang, 2009). Based on House cited in Wei and Wang (2009) there are four items that can be used to measure emotional support such as (i) concerning about the happiness and healthy in new venture creation, (ii) help individuals when he/she is in trouble in new venture creation and makes him/her feel better, (iii) make individuals relax when he/she feel exhausted in new venture creation, and (iv) make individuals feel comfort when he/she frustrated in new venture creation.

Social relationships are potential to offer useful resources which include emotional resources. These may take the form of emotional expression which may sustain an individual in the short or long term; instrumental emotional support which may help an individual to master their emotional burdens; coherence support which may be overt or covert information, resulting in confidence in the individual's preparation for a life event or transition; validation which may result in an individual feeling someone believes in them; an inclusion which 
may result in a sense a belonging.

Family support, or lack of it, is of essential importance in the decision-making process for the women entrepreneur and depending on the reaction from the family, the women entrepreneur can either be highly motivated in her new business or completely demotivated. The discouragement from the home, coupled with opposition from society at large creates emotional and physical barriers (Bulsara \& Pandurengan, 2007). Higher level of support includes a positive evaluation on oneself, motivation and acceptance expression on one's opinion. This support will assist to give meaningful feelings for others that sees themselves to possess different characteristic to other, therefore it can give birth to self-confidence and self-admiration for others (Sarafino,1994; Mustikawati \& Bachtiar, 2008).

High level of support is an aspect of social support that is given to others with the aim of promoting good feeling for others (Holmstrom \& Burleson, 2011). Self-esteem shows individual a complete emotion of one's value and self-independence. Esteem support is described as the honor giving to others by oneself. Esteem support is manifested in self-confidence or self-motivation. Others providing esteem support can identify one strength that is neglected or making one have confidence in one's ability.

Esteem support is the evaluation giving to others, explaining the approval and disapproval of the attitude to others. Self-esteem is the continuous process, resulting to a systematic development that is affected by new circumstances and happenings. Positive experience results to a giving amount of evaluations on one's self-esteem while a failure result to a gradual fall in one's self-esteem (Harris, 2006).

Support from faculty/college is very important for the development of student entrepreneurship. Lack of supports from the faculty could be one of an obstacle to the development of student entrepreneurship. One study found that, from 51 students surveyed, a total of 26 students were declared to be sufficient support from the faculty, the support of the faculty may be providing seminars, training, and mentoring entrepreneurs for free. The free entrepreneurial mentoring can also be assistance from building a business during the start-up to maturity. Some programs have also been carried out such as assisting prospective entrepreneurs through business incubator programs (Amalia, 2012).

In supporting people in entrepreneurship, the role of parents is not merely forming their personality to become a successful entrepreneur. The provision of capital is also one of the parents' roles to improve their motivation for entrepreneurship. The role of parents to support can be financial capital (finance), a tool and a place for entrepreneurship and investment. In addition to encouraging children to entrepreneurship, parents can also help with the form of infrastructure or business space. Capital in the form of money or place of business should not be too much and enforced. Despite, providing a small capital can be a form of support for their children to become entrepreneurs (Sari, 2012).

As mentioned by Susanti (2012) the instrumental support is a support in term of tangible assistance or actions provided by social familiarity. The direct social support such as the provision of equipment, jobs and finances. Social support is very much needed by the prospective entrepreneur. They need the support to start a business such as capital, loan, and so on. Information support is communication that provides useful or needed information. When facing any challenging circumstances, particularly in developing a business, usually information is necessary for making decision. Not knowing the details of what one is facing or about the different options available can be a source of upset and stress (Mattson's Health as Communication Nexus, 2011). Informational support is the provision of advice, guidance, suggestions, or useful information to someone. An individual who desires to start a venture usually needs more information relating to what kind of business could be generated nowadays and whether there are any competitors if he/she runs this business, etc.

Network support relates to the relationship that exists with other people, confirming their individual possession of socializing with other through the availability of social network. In other words, network support is communication that reminds people that they are not alone in whatever situation they are facing. Members of the network may offer many kinds of support but the concept of network support emphasizes that a network is available for providing social support (Mattson's Health as Communication Nexus, 2011).

Peer group is an initial realm of social interaction which include individual's decision to initiate a business due to the influence of his or her peers. Peers who are already running their own venture always try to provide him a comfort environment in his or her business startup (Bönte, Falck, \& Heblich, 2009). Peer pressure with regard to business leads toward other social influence like media, social networks and social organizations; therefore, it is easier for the one to take initiative for business.

One study found that by having an entrepreneurial peer group support, will generate positive effect on one's 
entrepreneurial desires (Falck, Heblich, \& Luedemann, 2009). In the presence of contextual effects, a student spending time at a peer's home with entrepreneurial parents is going to be more exposed to entrepreneurship as a career option than those who do not. Manski (1995) cited in Falck (2009) raises the possibility or spurious estimates of peer-group effects that may be erroneously interpreted as true endogenous or contextual effects: the so-called correlated effects. These can arise when youths in the same reference group express the same occupational intentions because they share a common set of overlooked characteristics.

Family plays a pivotal role in the business establishment process and therefore their role deserves greater contribution in the entrepreneurship. The kinship relationships provide the strongest connections in entrepreneurial networks. The family offers a range of resources in both professional and nonprofessional manner which is efficacious in nature. In the case of entrepreneur, network may be derived from membership of trade associations, business networks or indeed friendship with business people, which help the entrepreneur in providing the access to information (Leek \& Mason, 2003) (Zafar, 2012). One study found that affective family-to-business enrichment (the transfer of positive affect, e.g., positive mood or happiness, from the family domain to the work domain), instrumental family-to-business enrichment (the transfer of skills and behaviors acquired or nurtured in the family domain to the work domain) and family-to-business support (interpersonal support from family members) were positively related to entrepreneurial success and satisfaction for female business owners but not male business owners (Murphy, 2013). In addition, Murphy stated that Family-to-business support was more positively related to women's business performance, growth in employment, satisfaction with employee relationships, and satisfaction with a status than for male entrepreneurs. Affective family-to-business enrichment was more positively related to women's business performance, satisfaction with employee relationships, and satisfaction with a status than for male entrepreneurs. Instrumental family-to-business enrichment was more positively related to women's satisfaction with a status than for male entrepreneurs. Therefore, female entrepreneurs may benefit more from family-to-business enrichment and support than men because of their relative lack of access to other resources like social and financial capital. In addition, women's inclination to integrate work and family and to emphasize the interconnectedness and relationships may give them an advantage in capitalizing on sources of family-to-business enrichment and support.

\section{Problem Formulation}

There are many researchers contributed to the field of social support system's role in grooming a young graduate who was studying in universities ad business school to become entrepreneurs. However, these findings are topic specific not integrating varied models proposed by various authors in entrepreneurship. Many aspects like family, peer group, educational institutions, etc. have keen role in acting as a factor of social support system. It has been pointed out by Susanti (2012) that someone who dares to choose entrepreneurship as a career is a person who feels being trusted by people, feel comfortable, able to deal with any risks. Such behavior can grow and thrive in the person who receives social support. The encouragement such as strong motivation to move from the family is the initial capital to become an entrepreneur. With the support of the families, they can have a stronger mentality and high motivation as the main driving factor (Kasmir, 2006). Widiastuti (2005) cited in Mindo \& Retnanignsih (2008) also stated that the success of a person is supported by family atmosphere which includes the interaction of the person with his parents and brothers. In the family members, there is a process of interaction to each other to meet their individual goals and strive to meet the satisfaction of the social life in the family. It is obvious that someone who dares to choose entrepreneurship as a career is a person who feels being trusted by people, feel comfortable, able to deal with any risks. Such behavior can grow and thrive in the person who receive social support (Susanti, 2012).

However, in Indonesia, there is a thought that many parents expect their children become civil servants then their life would be better than to be entrepreneurs (Mustikawati \& Bachtiar, 2008). This assumption might be true that the attribute of an employee can raise the social status and the human personality to a certain extent, but the economic growth and development of Indonesia could not enhance or step higher if the number of entrepreneurs remains low. In addition to that, the interest in entrepreneurship will grow and thrive in a person who live and grow up in the environment of the entrepreneur's family. In fact, most of the family environment is not conducive to the formation of a person's interest in entrepreneurship. It is caused by many aspects such as; lack of knowledge of parents, the family mindset of being civil servants or employees is safer than being an entrepreneur, there is no model as entrepreneur in the family, etc. (Aprilianty, 2012). The achievement of students on their choosing career is not only the main support of the appearance for them, but the kind of education institution where they attended is more important. The duty of parents and the duty of professional school counselors most move side by side in the training of young adolescents. Schools lay down rules and regulation have and underlining regime to help students 
be equipped educationally and making decision for their career with the aim of supplying adequate resources and materials through a progressive and the comprehensive approach (Turner \& Lapan, 2002). Entrepreneurship is not appreciated as like an important and prestigious profession. There are quite a lot of examples of successful entrepreneurs in Indonesia. However, awards and high attention to someone who is pioneering the entrepreneurship efforts would not so encouraging. In the family environment, for instance, there are not many parents who introduce, encourage, and provide entrepreneurship training to their young ones. There are still so many parents who boast of seeing their son become employees of the private or public sector rather than being an entrepreneur which has unpredictable income (Hartanto, 2011; Mulyana, 2013). People who have a strong family support will be ready to face the capabilities and resources needed in entrepreneurship (Astuti, 2009). They will be more stable if they pursue a career as an entrepreneur. The results of a study in Spain involving 601 college students stated that there is a significant positive relationship between family, work context, entrepreneurship education, social support and the intense entrepreneurial individualism. The study results also indicated that the lack of entrepreneurship students due to the stimulation of entrepreneurial activities to create new business given by the university is still very low. Respondents also stated that her relatives (parents, siblings, spouse) who has a background in entrepreneurship more generally encourage them to pursue careers as entrepreneurs. Their friends or their lecturer otherwise does not encourage them to entrepreneurship (Astuti, 2009). Furthermore, most of the students lack confidence to broaden their insight on the field of entrepreneurship (Amalia, 2012).

All these researchers have pointed out the importance of social support system in grooming students to become young entrepreneurs. However, there are less number of studies have been conducted in Indonesian scenario to identify which are the variables that are closely knit with the social support theme in its contribution toward entrepreneurship among young graduates. Hence, contemporarily a student needs to be conducted by examining various models, theories, and recent review of literature, contextualizing the topic into Indonesian business school.

\subsection{Problem Statement}

Entrepreneurship is a profession carrying several elements of leadership, business knowledge, orientation etc., in addition to the support he/she obtain from the society. Even when individual's having the several entrepreneurial behavioral traits, many external factors influence entrepreneurial efforts, personality, attitude and to become and entrepreneur. These factors includes 'family support and peer support' specifically and which have the considerable influence of determining entrepreneurial success, noted by past researchers. It has been clearly incorporated in the literature that the family support can act as a moderating factor among entrepreneurs in the journey towards accepting entrepreneurship as a profession. Contextualizing the topic to Indonesian scenario where the young generation is more molding toward 'employee ship' rather 'entrepreneurship', how far the 'support system' influences their choice of profession need to be understood. Hence, this particular study identifies the topic of research as "variable analysis and model confirmation using the Delphi technique.

\section{Research Methodology}

This particular study followed Delphi technique as it design of method to explore categories and factors related to social support issues in various universities. As it is known, the Delphi technique is one of the methods, which started its usage in 1950, in order to get consensuses, which is linked to real world knowledge coming through experiences on the area related to research topics. It is pointed out by Dalkey (1972) that the consensus on decisions which is coming from heads is better than one, or... $\mathrm{n}$ heads are better than one. This Delphi technique is as consider one of the effective communication process with the objective of making deep analysis base on deliberation on a specific problem in order to set the goal, undertake a probe into the policy or to make effective prediction on the occurrence of future events (Kumar, 2013). Basically the Delphi technique is conducted in the form of semi-structure interaction and interview. High concentration on the process is envisaged to ensure the rigorous.

During the middle of march to the middle of November 2013 Delphi process organized among the resources people carefully selected based on the expertise knit with social support, followed by interviews.

Telephonic interview is utilized to collect information from the respondents. 40 professionals or expert from the industry and academia were recognized and approached by email or telephone and were invited to participate in the study. All the clarifications related to the objective of the study were made by the researcher. However, From 26 respondents were being interacted and communicated, only 20 respondents shown their enthusiasm to take a part in the discussion. Finally, the 20 participants were interviewed by telephone and through email. The conversations have been taped and recorded and manually analyzed. The procedural steps in adopting the Delphi technique were as follows. 


\subsection{Expert Panel Identification}

The group of professional was made from experts having high knowledge and expertise in social network and entrepreneurship. They are closely associated with industries like consultants, Owners of industries, Top level managers, Entrepreneurs, Professors, Researchers as well as Academicians. Based on the area of expertise, the expert members include 12 male members $(60 \%)$ and 8 female members $(40 \%)$. These dynamic groups of panel of experts are knowledgeable and familiar to give relevant opinions and an admissible understanding of the concept of social suppot.

\subsection{Rounds}

\subsubsection{Round 1}

In the initial round, the Delphi process essentially begins with an open-ended questionnaire. The open-ended questionnaire serves as the foundation of soliciting specific information about a contented area from the Delphi subjects (Custer, Scarcella, \& Stewart, 1999).

\section{The questions:}

1. How do you define social support?

2. How do you relate the social support with entrepreneurial learning and development?

3. Which are the main aspects, in general closely related to Social support?

4. Contextualizing the topic to the Indonesian scenario, which are the major factors, closely related to social support in Indonesia?

\subsubsection{Round 2}

The second round concentrate into categories and the items which are more closed to the concept social support. Followed by the procedure the Delphi members received the second questionnaire and accordingly they were required to rate or rank order the items in order to establish first level preferences among item incorporated into. In this stage, based on the decision and deliberation, agreement and disagreement on the items consider in relation to social support were make. Care should be taken that, the number on Delphi iteration should be based on how far consensuses have been arrived at effectively on the concept social support in the study. The process identifies 82 categories, which are having items with high and low proximity of entrepreneurial orientation identified. Rating process further identified in the categories and items identified.

\subsubsection{Round 3}

In this round, each Delphi panelist receives a number of questionnaires that include the categories and items ratings, summarized by the investigators in the previous cycle and are asked to revise his/her judgments or "to delineate the reasons for staying outside the consensus" (Pfeiffer, 1968). This round gives Delphi panelists a chance to make further explanations of both the information and their decisions about the relative importance of the categories and items. Second level screening of the 82 categories which were having a high and low influence on business incubation centers identified with corresponding items. The process further identified 38 categories, which are having high and low proximity of the social support identified. Classification of the items in 38 categories of 2 factors was being made with appropriate loaded items. Thematic presentation and the categorization of the items were done.

\subsubsection{Round 4}

This round is the last round in which the researchers tried to eliminate the minority opinion in order to capture the maximum level of consensus based on their rating on the categories and items which related to social support. Crosschecking of this categories and items were thoroughly make and the suitability clearly ascertained for fixing up the categories and items related the factor social support. During fourth level, screening of the 25 categories of 2 factors which were having items with high and moderately high proximity of social support identified. Sought the expert opinion on the appropriateness of the core factors selected for the study.

The first factor that linked to Social support is the Family Support. The experts identified 39 items under 13 categories in relation to social support. The major categories identified by the experts are the Encouragement from family members $(90 \%)$, providing financial assistance (90\%), assisting startups $(90 \%)$ and sharing problems (90\%). The expert further observed Support with useful information (85\%), Support with right advices (85\%), sharing responsibility $(85 \%)$, and providing self-confidence $(85 \%)$ Support in networking $(85 \%)$ and Identifying space and location (85\%). Though much difference in the scoring is further observed, the experts have given minor scoring three categories like Support in decision making (80\%) and Emotional Support (80\%) 
and Coordinating activities (80\%) which are closely knit with social support.

Table 1. Delphi application

\begin{tabular}{|c|c|c|c|c|c|c|c|}
\hline No & Factors & Categories & $\begin{array}{l}\text { No. } \\
\text { items }\end{array}$ & of & $\begin{array}{l}\text { No. } \\
\text { Experts } \\
(\mathrm{N}=20)\end{array}$ & $\begin{array}{l}\text { \% } \\
\text { Experts }\end{array}$ & of \\
\hline \multirow[t]{13}{*}{1} & Family Support & Support with useful information & 4 & & 17 & 85 & \\
\hline & & Support with right advices & 3 & & 17 & 85 & \\
\hline & & Support in decision making & 4 & & 16 & 80 & \\
\hline & & Encouragement from family member & 3 & & 18 & 90 & \\
\hline & & Sharing responsibility & 3 & & 17 & 85 & \\
\hline & & Emotional Support & 2 & & 16 & 80 & \\
\hline & & Providing self-confidence & 2 & & 17 & 85 & \\
\hline & & Providing financial assistance & 3 & & 18 & 90 & \\
\hline & & Assisting start ups & 3 & & 18 & 90 & \\
\hline & & Sharing problem & 3 & & 18 & 90 & \\
\hline & & Support in networking & 4 & & 17 & 85 & \\
\hline & & Identifying space and location & 2 & & 17 & 85 & \\
\hline & & Coordinating activities & 3 & & 16 & 80 & \\
\hline \multirow[t]{12}{*}{2} & $\begin{array}{l}\text { Peer Group } \\
\text { support }\end{array}$ & Motivation from friends & 3 & & 17 & 85 & \\
\hline & & $\begin{array}{l}\text { Making provision of adequate } \\
\text { information }\end{array}$ & 3 & & 17 & 85 & \\
\hline & & Providing right suggestions & 3 & & 17 & 85 & \\
\hline & & Facilitate better decision making & 3 & & 18 & 90 & \\
\hline & & Sharing responsibility & 3 & & 17 & 85 & \\
\hline & & Providing psychological support & 2 & & 16 & 80 & \\
\hline & & Inducing self-confidence & 2 & & 16 & 80 & \\
\hline & & Sharing business problem & 3 & & 17 & 85 & \\
\hline & & Supporting start-up & 3 & & 17 & 85 & \\
\hline & & Networking support & 3 & & 17 & 85 & \\
\hline & & Identifying good location & 2 & & 16 & 80 & \\
\hline & & Supporting coordination & 3 & & 16 & 80 & \\
\hline
\end{tabular}

The last factor considered for the study is the Peer Group Support. The result shows that the professionals identified 33 items which come under 12 categories social support factor. The table showed that Facilitating better decision making $(90 \%)$ as the prominent factor which closely knit with social support for the students. The experts also identified Motivation from friends (85\%), Making provision of adequate information (85\%), Providing right suggestion (85\%), and Sharing responsibility (85\%), Sharing business problem (85\%), supporting startup (85\%) and Networking support (85\%) as the second prominent factors in relation to social support among students. Moreover the result also shows the importance of categories like Providing psychological support (80\%), Inducing self-confidence (80\%), Identifying good location (80\%) and supporting coordination $(80 \%)$ that are knit with social support for the students.

\section{Discussion}

This particular study on understanding family seldom supports factor and fixing those variables for further studies has identified two major factors which include the family support and the peer support that would facilitate the students to become an entrepreneur. In the review of the literature and problem formulation part, it has been clearly cited that the Indonesian family seldom supports their youngsters to become entrepreneurs. Mustikawati and Bachtiar (2008) rightly point out in this context that in Indonesia there is a thought that many 
parents expect their children to become a civil servant and their life would be better than to be entrepreneurs. With due consideration to this quotation, it is very important to assess various moderating factors that influence student entrepreneurial orientation and their intention to take up entrepreneurship as their profession.

The first factor identified by the expert in this particular research was the family support. It is pointed out by Kashmir (2006) that with the support of families, the student can have a stronger mentality and high motivation as the main driving factor. Further, substantiating this argument, Widiastuti (2005) also stated that the success of a person who is supported by family atmosphere which includes the interaction with his parents and brothers that support them to become entrepreneurs. Under the family support, the expert were identified many factors like encouragement from family members, providing support with useful information, making provision of right advices, giving support in decision making, sharing the responsibility of new ventures, inducing emotional support, inducing self-confidence, providing financial assistance, assisting start up, sharing entrepreneurial problem, providing support and networking, identifying appropriate space for starting the business and coordination of activities. In all these factors, family role is very important. It is expected that the family members should provide adequate psychological, financial, social, and allied support facilities for the youngsters to become entrepreneurs. Any forms of discouragement the youngsters feel from the institution of family develop there by demotivation, lack of self-confidence and disappointment among youngsters. So, in this context the categories pointed out by the expert are very important in measuring young students' desire on intention to become an entrepreneur.

The second factor identified by the experts in this research includes, the support, the young students receive from their peer groups. Just as, the support a student expect from the family members, they also expect appropriate support from their peer groups. The students should get appropriate motivation in taking the right decision, related to starting up a business with effective support and coordination. Under peer group support, the experts have identified many categories like motivation from friends, making provision of adequate information, providing right suggestion, getting support in right decision-making, sharing all responsibilities related to new venture ship, providing adequate psychological support, inducing self-confidence, sharing the new business problems, support in starting up new business, providing effective networking support, identifying the right location to start the business, and provide support in effective coordination and activities, are all very important in grooming students toward entrepreneurial motivation. The motivation and self-confidence the students derived from the same age group people will sustain their vision to become an entrepreneur.

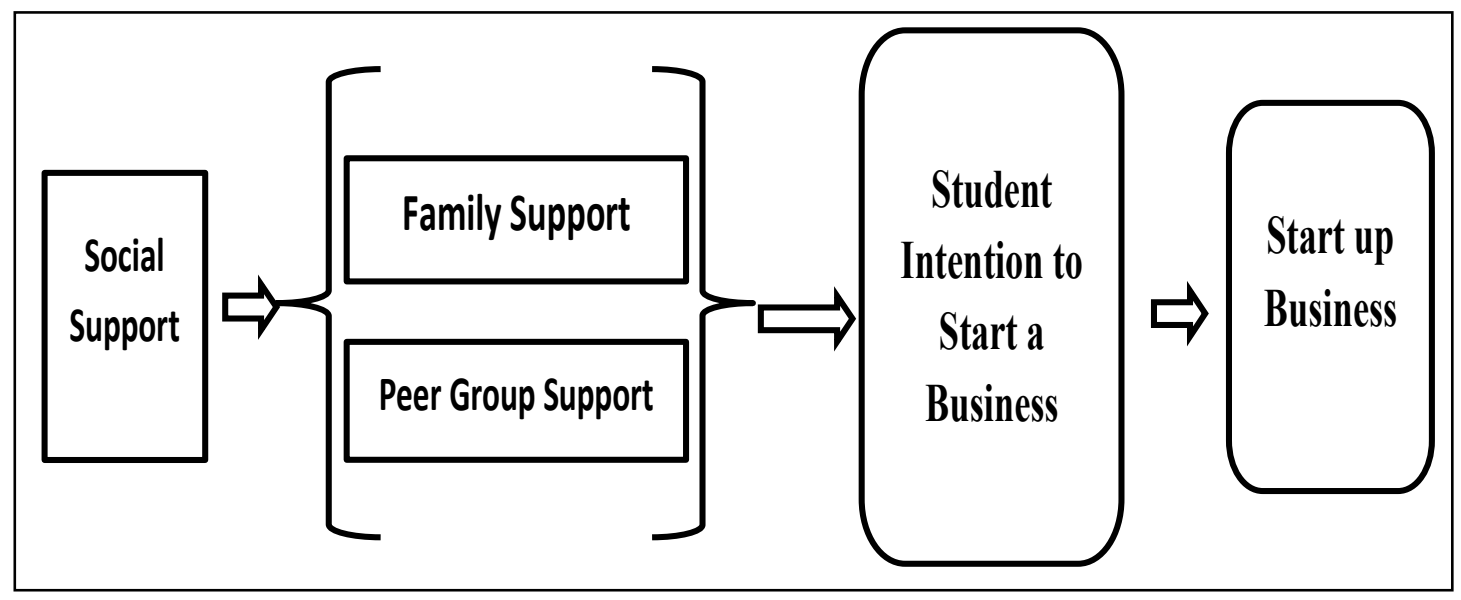

Figure 1. Model: Factors related to social support

Hence, the social support is a factor which may have a moderating effect of entrepreneurial orientation and the student's intention to become entrepreneurs. The social support is viewed as one of the basic blocks of social, psychological and biological integrity. These social supports act as formal and informal support factors which is considered as center components of individual social capital that contribute to their vision to become entrepreneur. It acts as a perception and actuality that one is totally taken care of by their family and their peer groups by extending appropriate assistance to realize their goal to become an entrepreneur. It has been rightly pointed out by Lion (2007) that social support act as potential entrepreneur belief and expectation about the support he or she will receive from the group to which he or she belongs which include the parent, siblings and spouse and from other reference group like the friends, the colleagues and the teachers in the case of setting up a 
business or going self-employment. Hence, the factors identified by the expert need to be further analyzed with the support of extensive research.

\section{Implication}

The objective of this particular research was to identify and fix variables related to the social support factors which influence a student decision to become an entrepreneur. This research identified two factors (family and peer support) and 25 Categories to explore the relationship between student entrepreneurial intention and social support system. In order to identify the social support factors, this particular study followed many models like Sarafino (1994), House and Khan (1985), House (1981), Gottlieb (2000), Mattson (2011), etc. These models have segregated the social support factors into many sub factors like emotional support, esteem support, instrumental support, informational support, material support, etc. While the experts have the opinion that these factors can be clubbed together into two major factors like family support and peer support. These are the major institution which influences with their supporting facility to the youngster in making their goal towards entrepreneurship. These two institutions having far reaching influence and develop social collaborated psychological, economical, infrastructural and spiritual implications further to their decision to become a young entrepreneur or start up a new business venture. Hence, by incorporating factors like the family and peer group support with the major theme social support, further study to be conducted with quantitative research to prove these variables acceptance as major factors moderating entrepreneurial orientation and intention.

\section{Conclusion}

Several theories models and recent findings are available to understand the social support factors in relation to students' intention to become an entrepreneur. Contextualizing the topic to Indonesian student scenario, how far these theories and models that rooted from the west is adoptable that need to be further explored. Keeping in mind the objective of customizing the variables to the Indonesian context, all the theories and models of social support factors are thoroughly evaluated into and finally segregated into two major factors like family support and peer support. This segregation of factors further helps the researchers to identify the categories related to each factor and well envision that these factors to be further exposed to extensive research with the support of quantitative research. It is also directed by the researchers that these factors should be subjected to factor analysis to ascertain the validity and reliability on the factors loaded and the items incorporated. A mixed method of qualitative and quantitative method may thereby provide a better predicting variable toward entrepreneurial intention among young graduates of Indonesia.

\section{References}

Agustina, T. S. (2011). Pean Inkubator Bisnis Perguruan Tinggi Dalam Meminimalkan Resiko Kegagalan Bagi Wirausaha Baru Pada Tahap Awal (Start-Up). Majalah Ekonomi, (1), 64-74. Retrieved from http://journal.lib.unair.ac.id/index.php/ME/article/view/834/829

Amalia. (2012). Kendala Berwirausaha Dikalangan Mahasiswa. Retrieved from http://manajemen.unnes.ac.id/ wp-content/uploads/2013/01/Kendala-Berwirausaha-Dikalangan-Mahasiswa.pdf

Aprilianty, E. (2012). Pengaruh Kepribadian Wirausaha, Pengetahuan Kewirausahaan, dan Lingkungan Terhadap Minat Berwirausaha Siswa SMA. Jurnal Pendidikan Vokasi, 2(3), 311-324.

Astuti, D. A. W. (2009). Pengaruh Konteks Keluarga, Kerja, Pendidikan, Hambatan Dalam Memulai Bisnis, Dukungan Sosial, Nilai-Nilai Individualisme dan Kolektivisme Pada Intensi Berwirausaha.

Baron, R. A., \& Markman, G. D. (2000). Beyond social capital: How social skills can enhance entrepreneurs' success. Academy of Management Perspectives, 14(1), 106-116. http://dx.doi.org/10.5465/AME.2000. 2909843

Bönte, W., Falck, O., \& Heblich, S. (2009). The Impact of Regional Age Structure on Entrepreneurship. Economic Geography, 85(3), 269-287. http://dx.doi.org/10.1111/j.1944-8287.2009.01032.x

Brock, R. L., \& Lawrence, E. (2009). Too much of a good thing: Under provision versus overprovision of partner support. Journal of family psychology: JFP: Journal of the Division of Family Psychology of the American Psychological Association (Division 43), 23(2), 181-192.

Bulsara, H. P., \& Pandurengan, V. (2007). Developing Women Entrepreneurship: A Challenge. In P. Jyothi (Ed.), Entrepreneurship: Issues and Challenges (pp. 387-406). India: Allied Publications Pvt. Ltd.

Cobb, S. (1985). Social Support as a Moderator of Life Stress. Psychosom. Brown University, Providence, RI. $\mathrm{CC} /$ Number. 
Custer, R. L., Scarcella, J. A., \& Stewart, B. R. (1999). The modified Delphi technique: A rotational modification. Journal of Vocational and Technical Education, 15(2), 1-10.

Dalkey, N. C. (1972). The Delphi method: An experimental study of group opinion. In N. C. Dalkey, D. L. Rourke, R. Lewis, \& D. Snyder (Eds.), Studies in the quality of life: Delphi and decision-making (pp. 13-54). Lexington, MA: Lexington Books. Ludwig, 1994.

Falck, O., Heblich, S., \& Luedemann, E. (2009, July 10). Identity and entrepreneurship: Do school peers shape entrepreneurial intentions? Small Business Economics.

Goodwin, R., Costa, P., \& Adonu, J. (2004). Social support and its consequences: "Positive" and "deficiency" values and their implications for support and self-esteem. The British journal of social psychology/the British Psychological Society, 43, 465-474.

Hardiningtyas, D. (2011). Sharing Matching Dunia Kerja dan Lulusan Pendidikan Indonesia. University of Brawijaya. Retrieved November 12, 2013, from http://dewihardiningtyas.lecture.ub.ac.id/files/2012/04/ Sharing-dunia-kerja-dan-motivasi-diri.pdf

Harris, J. G. (2006). Self-Esteem, Family Support, Peer Support, and Depressive Symptomatology: A Correlational Descriptive Study of Pregnant Adolescents. Georgia State University.

Hartanto, E. F. (2011). Kendala Berwirausaha di Indonesia. Retrieved December 11, 2013, from http://research.amikom.ac.id/index.php/ KIM/article/view/3933/2272

Holmstrom, A. J., \& Burleson, B. R. (2011). An Initial Test of a Cognitive-Emotional Theory of Esteem Support Messages. Communication Research, 38(3), 326-355. http://dx.doi.org/10.1177/0093650210376191

Hupcey, J. E. (1998). Clarifying the social support theory-research linkage. Journal of Advanced Nursing, 27(6), 1231-1241. http://dx.doi.org/10.1046/j.1365-2648.1998.01231.x

Kasmir. (2006). Kewirausahaan. Jakarta: Raja Grafindo Persada. Retrieved from http://library.um.ac.id

Klyver, K., \& Schøtt, T. (2011). How Social Network Structure Shapes Entrepreneurial Intentions? Journal of Global Entrepreneurship Research, 1(1), 3-19.

Kumar, D. K. (2013). Ways and Means of Research Method. Research India Publications. New Delhi.

León, J. A. M., Descals, F. J. P., \& Domínguez, J. F. M. (2007). The Psychosocial Profile of The University Entrepreneur. Journal of Psychology in Spain. Retrieved December 11, 2013, from http://www.academia. edu/229127/The_Psychosocial_Profile_of_The_University_Entrepreneur

Loo, V. E. (2006). Responsible Leadership at ABN AMRO Real. In T. Maak, \& N. M. Pless (Eds.), Responsible Leadership (pp. 170-181). PriceWaterhouse Coopers. Oxon: Routledge.

Lopez, M. L., \& Cooper, L. (2011). Social Support Measures Review. National Centre for Latino Child \& Family Research. Retrieved from http://www.first5la.org/files/SSMS_LopezCooper_LiteratureReview andTable_02212011.pdf

Mair, J., \& Noboa, E. (2003). Social Entrepreneurship: How Intentions to Create a Social Enterprise Get Formed. IESE Business School: University of Navarra.

Mattson's Health as Communication Nexus. (2011). In S. I. Junker (Ed.), Linking Health Communication With Social Support (pp. 181-218). Kendall Hunt Publishing Co.

Mead, S., Hilton, D., \& Curtis, L. (2001, January). Peer support: A theoretical perspective. Psychiatric rehabilitation journal. Retrieved December 20, 2013, from http://www.peerzone.info/sites/default/files/ resource_materials/PeerSupportATheoreticalPerspective Mead.pdf

Mindo, R. R., \& Retnaningsih. (2008). Relationship between Social Support Parents in Children with Learning Achievement Elementary School. Jakarta.

MIS. (2011). Information Systems: Definitions and Components. Retrieved December 31, 2013, from http://www.uotechnology.edu.iq/sweit/Lectures/SarmadFuad-MIS/MIS_Lecture_3.pdf

Mulyana, R. A. (2013). Pengaruh Norma Subjektif, Persepsi Kontrol Perilaku, Dan Sikap Wirausaha Terhadap Minat Berwirausaha Siswa SMK. Universitas Pendidikan Indonesia.

Murphy, C. (2013). Family Support Linked to Entrepreneurial Success Among Women. O\&P Business News. Retrieved December 18, 2013, from http://www.healio.com/orthotics-prosthetics/human-resources/ news/print/o-and-p-business-news/\{2fd58362-e44d-4081-8624-d3d8c925314a\}/family-support-linked-to-e 
ntrepreneurial-success-among-women

Mustikawati, I., \& Bachtiar, M. (2008). Hubungan Antara Dukungan Sosial (Orangtua) Dengan Minat Berwirausaha Pada Siswa Sekolah Menengah Kejuruan Oleh : Fakultas Psikologi Dan Ilmu Sosial Budaya Universitas Islam Indonesia Yogyakarta. Yogyakarta.

Peplau, L. A. (1985). In I. G. Sarason, \& B. R. Sarason (Eds.), Social Support: Theory, Research and Applications. Washington: Martinus Nijhoff Publishers.

Pfeiffer, J. (1968). New look at education. Poughkeepsie, NY: Odyssey Press.

Rasheed, S., Sawal, M., Taj, R., \& Najam, N. (2005). Relationship between suicidal ideation, social support and coping skills in female prisoners of a jail in Pakistan. Journal of Pakistan Psychiatric Society (JPPS), 2(2). Retrieved from http://www.jpps.com.pk/display_articles.asp?d=106\&p=art

Sarason, I. G., Sarason, B. R., Shearin, E. N., \& Pierce, G. R. (1987). A Brief Measure of Social Support: Practical and Theoretical Implications. Journal of Social and Personal Relationships, 4(4), 497-510. http://dx.doi.org/10.1177/0265407587044007

Sari, A. (2012). The Entrepreneurial Readiness of the Students of the Food \& Beverage Skill Competency in Public Vocational High Schools. Journal Pendidikan Vokasi, 2(2), 154-168.

Schumpeter, J. A. (1934). The Theory of Economic Development: An Inquiry into Profits, Capital, Credit, Interest, and the Business Cycle. Cambridge MA: Harvard University Press.

Schwarzer, R., \& Rieckmann, N. (2000). Social Support, Cardiovascular Disease, and Mortality. Berlin, Germany.

Scott, E. (2012). Types of Social Support: How Do Different Types of Social Support Work? Retrieved December 31, 2013, from http://stress.about.com/od/relationships/a/types-of-social-support.htm

Susanti, N. (2012). Hubungan Antara Dukungan Sosial Dan Daya Juang Dengan Orientasi Wirausaha Pada Mahasiswa Program Profesi Apoteker Universitas Ahmad Dahlan Yogyakarta. Retrieved from http://uad-journal.com/index.php/EMPATHY/article/download/1548/886

Turner, S., \& Lapan, R. T. (2002). Career self-efficacy and perceptions of parent support in adolescent career development. National Career Development Association, 51(1). Retrieved from http://www.freepatents online.com/article/Career-Development-Quarterly/92036446.html

Vadnjal, J., \& Vadnjal, M. (2013). The role of husbands: Support or barrier to women's entrepreneurial start-ups, 7(36), 3730-3738.

Wei, X., \& Wang, C. (2009). Research on the Contents and Structure of Social Support for Private Entrepreneurs. Asian Social Science, 5(2), 11-14. http://dx.doi.org/10.5539/ass.v5n2p11

William, P. (2005). What is Social Support? A Grounded Theory of Social Interaction in the Context of the New Family. Retrieved December 24, 2013, from digital.library.adelaide.edu.au/dspace/bitstream/2440/.../1 /02whole.pdf

Zafar, M., Yasin, G., \& Ijaz, M. (2012). Social Networking A Source For Developing Entrepreneurial Intentions Among Entrepreneurs: A Case Of Multan. Asian Economic and Financial Review, 2(8), 1072-1084. Retrieved from http://aessweb.com/journal-detail.php?id=5002

\section{Copyrights}

Copyright for this article is retained by the author(s), with first publication rights granted to the journal.

This is an open-access article distributed under the terms and conditions of the Creative Commons Attribution license (http://creativecommons.org/licenses/by/3.0/). 